\title{
ADPF: A DEFESA DOS PRECEITOS FUNDAMENTAIS NO CONTROLE JUDICIAL DE ATOS POLÍTICOS
}

Felipe Jacques ${ }^{1}$

Antônio Bastos ${ }^{2}$

Resumo: Neste estudo, a Arguição de Descumprimento de Preceito Fundamental é apresentada como importante ação constitucional que se presta à tutela dos preceitos fundamentais violados ou ameaçados de violação por atos do Poder Público. Por essa razão, será questionada a jurisprudência do Supremo Tribunal Federal que afasta do objeto da ADPF os atos políticos, uma vez que estes também são praticados pelo Poder Público, demonstrando que a Suprema Corte tem vacilado em seu entendimento e pode está perdendo importante oportunidade de conferir normatividade plena à Constituição Federal de 1988.

Palavra-Chave: Preceito fundamental; ato político, Supremo Tribunal Federal, ADPF.

\section{ADPF: THE DEFENSE OF FUNDAMENTAL PRECEDENTS IN THE JUDICIAL CONTROL OF POLITICAL ACTS}

\begin{abstract}
In this study, the Argument of Non-compliance with Fundamental Precept is presented as an important constitutional action that lends itself to the protection of fundamental precepts violated or threatened with violation by acts of the Public Power. For this reason, the case law of the Federal Supreme Court will be questioned, which removes from the object of the ANFP the political acts, since these are also practiced by the Public Power, demonstrating that the Supreme Court has hesitated in its understanding and may be missing an important opportunity of to give full normativity to the Federal Constitution of 1988.
\end{abstract}

Key Word: Precept fundamental; Political act, Supreme Federal Court, ANFP.

\footnotetext{
${ }^{1}$ Felipe Jacques é doutorando e mestre em Direito pela UFBA, Especialista em Direito Civil pela Fundação Faculdade de Direito da UFBA, advogado sócio fundador do escritório Antônio Bastos \& Felipe Jacques Advocacia Especializada.

${ }^{2}$ Antônio Bastos possui graduação em Direito pelo Centro Universitário Jorge Amado (2008). Mestre pela Universidade Católica do Salvador - UCSAL (2016). Especialista em Direito Médico pelo Centro Universitário Leonardo da Vinci (2016). Especialista em Direito Processual Civil pela Fundação Faculdade de Direito - Universidade Federal da Bahia - UFBA (2011). Atualmente é advogado e professor Universitário e de Pós- Graduação. Docente e Coordenador do Curso de Direito da Faculdade Metropolitana de Camaçari - FAMEC e da Faculdade Anísio Teixeira - FAT. Professor Convidado da Pósgraduação UNIFACS. Tem experiência na área de Direito, com ênfase em Direito Processual Civil; ênfase em Direito Civil; ênfase em Direito Médico.
} 


\section{INTRODUÇÃO}

O Estado de Direito exige a subordinação da estrutura de desempenho do poder político-administrativo às normas constitucionais, sendo o Poder Judiciário o principal responsável pelo controle da observância da ordem constitucional.

O modelo de Estado subordinado às normas jurídicas, herança do constitucionalismo moderno, não trouxe respostas claras acerca do limite de controle dos atos do Poder Público por meio de decisões judiciais.

$\mathrm{O}$ advento do neoconstitucionalismo, em resposta aos terrores da segunda guerra mundial e a consequente aniquilação de direitos fundamentais com o aval do Estado de Direito nazista e fascista, ressaltou a importância de proteção de diretos tidos como essências e estruturantes da própria sociedade, dentre os quais têm especial destaque os direitos fundamentais. Esse período tem como consequências, a consolidação da supremacia da constituição e a concepção da eficácia expansiva dos valores constitucionais, que se irradiam por todo o sistema jurídico.

A partir desse momento, a jurisdição constitucional ganha especial relevância, passando a ser composta por importantes ações de tutela das normas constitucionais, tratandose de verdadeiro sistema de proteção e garantia da supremacia da constituição.

No Brasil da Constituição Federal de 1988, dentre as ações constitucionais integrantes do mencionado sistema, destaca-se a arguição de descumprimento de preceito fundamental ADPF, uma vez que tem por finalidade a proteção do que há de mais nobre e importante em uma Lei Fundamental, aquilo que diz respeito à própria essência, ao espírito da ordem constitucional, nada mais que os preceitos fundamentais, em face dos atos do Poder Público.

A posição de supremacia da constituição traz consigo o questionamento sobre os limites de proteção das normas constitucionais em face do desempenho das atribuições do Estado. Deveras, em algumas situações, princípios prevalecerão perante outros também constitucionais, e regras constitucionais deixarão de ser aplicadas em privilégio de outras de hierarquia semelhante. No entanto, quando o ato do Poder Público estiver em rota de colisão com as normas mais essenciais da ordem constitucional, resta o questionamento de como deve proceder a atuação do Poder Judiciário.

A busca de uma resposta para a mencionada indagação deve perpassar por dois questionamentos, quais sejam, o tipo de ato praticado pelo Estado e se este pode ou não ser objeto do controle jurisdicional. 
Os atos essenciais praticados pelo Poder Público são inerentes às funções dos Poderes constituídos, sendo estas: função de legislar, função de julgar, função administrativa, função de governo e função de fiscalização e controle. Embora cada um dos Poderes tenha sua função típica, também desenvolvem de forma atípica quase todas as demais. Por essa razão, os atos do Poder Público denominados políticos podem ser identificados na atuação de cada um dos Poderes constituídos, mas sobretudo na função de governo. Esses atos são alguns dos quais, atualmente, o Supremo Tribunal Federal consolidou jurisprudência contrária à apreciação pelo Poder Judiciário.

A análise acerca da possibilidade de superar esse entendimento passa, indubitavelmente, pelo instrumento da arguição de descumprimento de preceito fundamental, sendo importante propor um estudo que atenda aos seguintes propósitos: 1) traçar o histórico e apresentar algumas peculiaridades da ADPF; 2) entender a concepção de preceitos fundamentais; 3) compreender em que consiste o "descumprimento" de preceito fundamental por ato do Poder Público, e 4) examinar os atos políticos como possíveis objetos do controle judicial.

\section{2) DEFINIÇÃO DE PRECEITO FUNDAMENTAL}

A arguição de descumprimento de preceito fundamental tem um parâmetro de controle próprio e singular, qual seja, os preceitos fundamentais.

Na lição de Dirley da Cunha Jr., a ADPF não foi a primeira ação do controle concentrado de constitucionalidade a prever sua aplicação apenas a determinadas normas constitucionais, uma vez que já na Constituição brasileira de 1934 foi prevista uma ação específica para a proteção dos princípios constitucionais sensíveis, denominada de representação para fins de intervenção (representação interventiva), atualmente denominada de ação direta de inconstitucionalidade interventiva, com previsão no art. 36, III, e princípios tutelados no art. 34, VII, da Magna Carta de $1988^{3}$.

Ocorre que, em contraposição à representação interventiva, ADPF não se aplica a um rol taxativo de princípios constitucionais, portanto, faz-se necessário indagar quais seriam os preceitos fundamentais que merecem a especial proteção desta ação constitucional.

\footnotetext{
${ }^{3}$ CUNHA JR, Dirley da. Controle de Constitucionalidade: teoria e prática. 8a ed. Salvador: JusPodivm, 2016. p. 322.
} 
Em princípio, é importante saber o que é “preceito”, para poder delimitar o âmbito de abrangência da ADPF. Em sentido gramatical, a nomenclatura é sinônimo de "1. Regra de Proceder, norma; 2. Ensinamento, doutrina; 3. Ordem, determinação, prescrição”" , em sentido jurídico remonta a ideia de “conduta juridicamente desejável”, portanto, o mesmo conceito atribuível às normas jurídicas. Assim, a conclusão lógica é que “preceito” e “norma” são o mesmo instituto, como pontua com propriedade Dirley da Cunha Jr:

\begin{abstract}
Ora, se juridicamente a noção de preceito está relacionada à ideia de "comando", de "mandamento" de "ordem"; e se inexiste, no plano científico, a modalidade autônoma preceito, ao lado da modalidade norma, a conclusão a que se chega é que preceito e norma são categorias sinônimas 5 .
\end{abstract}

A conclusão de que preceito e norma são o mesmo instituto faz com que tenhamos duas espécies de preceitos, quais sejam: princípios e regras.

A partir de então, indaga-se sobre o conteúdo do preceito. O adjetivo "fundamental" que se segue ao preceito não responde ao questionamento, uma vez que remete apenas ao caráter constitucional da norma. Ocorre que as normas da constituição, por encontrarem-se ungidas pelo princípio da unidade, não podem ter hierarquias diferentes.

Embora, em aspecto formal, a Carta Constitucional deva ser considerada em sua unicidade, não se deve desconsiderar a ordem de valores jurídicos que suas normas têm na sociedade. Assim, as normas essencialmente constitucionais, quais sejam, as que versam sobre: i) organização do Estado (forma federativa de Estado e competência dos entes políticos, por exemplo); ii) estrutura política (atribuições do Presidente da República e do Congresso Nacional, exemplificativamente), e iii) direitos deveres e garantias da pessoa (direitos e garantias individuais e direitos sociais, por exemplo), têm inevitavelmente, maior relevância que outras normas dispersas na constituição, que foram inseridas por questões de conveniência do legislador constituinte ${ }^{6}$.

\footnotetext{
${ }^{4}$ Dicionário Aurélio <https://contas.tcu.gov.br/dicionario/home.asp> em 28/03/2017.

I - quando for relevante o fundamento da controvérsia constitucional sobre lei ou ato normativo federal, estadual ou municipal, incluídos os anteriores à Constituição

${ }^{5}$ Op Cit. p. 323-324.

${ }^{6}$ São exemplos de normas formalmente constitucionais:
}

Art. 242. (...)

$\S 2^{\circ}$ O Colégio Pedro II, localizado na cidade do Rio de Janeiro, será mantido na órbita federal.

Art. 243. As propriedades rurais e urbanas de qualquer região do País onde forem localizadas culturas ilegais de plantas psicotrópicas ou a exploração de trabalho escravo na forma da lei serão expropriadas e destinadas à reforma agrária e a 
Ocorre que, mesmo entre as mencionadas normas essenciais, também conhecidas como materialmente constitucionais, existem algumas cunhadas com o caráter de indisponibilidade, ou seja, normas que são indispensáveis à manutenção do Estado conforme consolidado na Constituição. Neste sentido importante trazer à baila os ensinamentos de Dirley da Cunha Jr:

Nesse contexto, pode-se conceituar preceito fundamental como toda norma constitucional - norma-princípio e norma-regra - que serve de fundamento básico de conformação e preservação da ordem jurídica e política do Estado. São as normas que veiculam os valores supremos de uma sociedade, sem os quais a mesma tende a desagregar-se, por lhe faltarem os pressupostos jurídicos e políticos essenciais. Enfim, é aquilo de mais relevante em uma Constituição, aferível por sua nota de indisponibilidade. É o seu núcleo central, a sua alma, o seu espírito, um conjunto de elementos que lhe dão vida e identidade, sem o qual não a falar em Constituição 7 .

Os preceitos fundamentais agregam os valores mais importantes de uma sociedade, contemplando normas essenciais à conservação do Estado conforme concebido pela Carta Magna.

Reconhecer o caráter indisponível dos preceitos fundamentais não é o suficiente para se estabelecer de forma hermética quais as normas da constituição são preceitos fundamentais. Uma vez que a constituição estabelece normas com caráter dinâmico de valoração, cabendo a hierarquia axiológica ao momento por que passa à sociedade e a composição ideológica do tribunal ao qual, em último grau, compete à interpretação da Constituição. Esses fatores permitem a mudança na valoração de uma norma e, portanto, a possibilidade de alteração de seu status para ser ou deixar de ser considerado um preceito fundamental.

Essa é a razão pela qual laborou bem o legislador constituinte originário e o legislador infraconstitucional, ao deixar de estabelecer um rol taxativo de normas que deveriam ser consideradas como preceitos fundamentais, diferentemente do que foi feito com os princípios constitucionais sensíveis objetos da ação direta de inconstitucionalidade interventiva.

Neste sentido pontifica Zeno Veloso:

Não nos parecia que o legislador ordinário pudesse indicar os preceitos fundamentais decorrentes da Constituição, cujo descumprimento possibilitaria a argüição. Significaria dar prerrogativa ao Congresso Nacional de eleger, dentro dos princípios, quais os que são fundamentais, vale dizer, essenciais, preponderantes,

programas de habitação popular, sem qualquer indenização ao proprietário e sem prejuízo de outras sanções previstas em lei, observado, no que couber, o disposto no art. $5^{\circ}$.

${ }^{7}$ Op Cit. p. 325. 
superiores. Ora, isto é atribuição do constituinte originário, ou do Supremo Tribunal Federal, guardião principal e intérprete máximo do Texto Magno. Além do mais, não poderia o legislador apresentar um elenco definitivo, um painel pronto e acabado dos preceitos fundamentais, pois a Constituição, apesar do ideal de estabilidade, é um documento histórico-cultural do povo. Embora lentas, as transformações são inevitáveis, ditando, como disse Krüger, uma mudança de natureza das normas constitucionais. O que hoje se pode considerar preceito fundamental, dada a dinamicidade do ordenamento jurídico, pode ter a sua densidade normativa diminuída no decorrer do tempo. (...) Estes são princípios reitores, regras nucleares, linhas mestras ou vigas-mestras da organização política e social brasileira, sem olvidar que há preceitos fundamentais que deles decorrem, havendo necessidade, para descobri-los de ser feita uma inferência, um desenvolvimento por parte do intérprete ${ }^{8}$.

A ausência de uma previsão expressa fez com que a doutrina se dedicasse a esse mister, com o objetivo de viabilizar o manejo da arguição de descumprimento de preceito fundamental e garantir maior segurança jurídica. Por essa razão, Nelson Nery Jr. e Rosa Maria Nery passaram a defender que:

São fundamentais, entre outros, os preceitos constitucionais relativos: ao estado democrático de direito (CF $1 .^{\circ}$ caput); b) à soberania nacional (CF $\left.1 .^{\circ} \mathrm{I}\right)$; c) à cidadania (CF 1. $\left.{ }^{\circ} \mathrm{II}\right)$; d) à dignidade da pessoa humana (CF $\left.1 .{ }^{\circ} \mathrm{III}\right)$; e) aos valores sociais do trabalho e da livre iniciativa (CF $\left.1 .^{\circ} \mathrm{IV}\right)$; f) ao pluralismo político (CF $1 .^{\circ}$ V); g) aos direitos e garantias fundamentais ( $\left.\mathrm{CF} 5^{\circ}\right)$; h) aos direitos sociais (CF 6..$^{\circ}$ 9. $\left.{ }^{\circ}\right)$; i) à forma federativa do estado brasileiro; j) à separação e independência dos poderes; l) ao voto universal, secreto, direto e periódico9.

A doutrina passa a trazer importante contribuição, tendo em conta que a constituição é instrumento jurídico aberto à interpretação, daí também outra nota de seu dinamismo. Ocorre que, ao fim e ao cabo, o mais importante interprete da Constituição é o próprio Supremo Tribunal Federal, razão pela qual André Ramos Tavares assevera que:

(...) é preciso insistir que o correto dimensionamento de cada um dos preceitos fundamentais dar-se-á por obra do Tribunal Constitucional, identificando, em cada caso a ele submetido, a ocorrência ou não de violação a determinado preceito fundamental, com o que acabará, inexoravelmente, apontando e construindo, pouco a pouco, o conteúdo dos preceitos fundamentais ${ }^{10}$.

\footnotetext{
${ }^{8}$ VELOSO, Zeno. Controle jurisdicional de constitucionalidade. 2003, p. 295 e 296.

${ }^{9}$ NERY JR., Nelson; NERY, Rosa Maria. Código de processo civil comentado e legislação processual civil extravagante em vigor. 2002, p. 1478.

${ }^{10}$ TAVARES, André Ramos. Tratado de Arguição de Preceito Fundamental. São Paulo: Atlas, 2001. p.154.
} 
As lições de André Ramos Tavares foram confirmadas por meio das decisões proferidas pelo Supremo Tribunal Federal em sede de ADPF. A mais importante nesse sentido foi a ADPF 33, de relatoria do ministro Gilmar Ferreira Mandes, em que restaram apresentadas algumas das normas constitucionais que atualmente são consideradas preceitos fundamentais ${ }^{11}$. No mesmo sentido, no julgamento da ADPF 45, o Relator, Ministro Celso de Melo também procurou definir a extensão dos preceitos fundamentais ${ }^{12}$.

Assim, pode-se afirmar com segurança que o Supremo Tribunal Federal, atualmente, entende ser preceito fundamental, as seguintes normas constitucionais:

\footnotetext{
${ }^{11}$ Parâmetro de controle — É muito difícil indicar, a priori, os preceitos fundamentais da Constituição passíveis de lesão tão grave que justifique o processo e o julgamento da argüição de descumprimento. Não há dúvida de que alguns desses preceitos estão enunciados, de forma explícita, no texto constitucional. Assim, ninguém poderá negar a qualidade de preceitos fundamentais da ordem constitucional aos direitos e garantias individuais (art. $5^{\circ}$, dentre outros). Da mesma forma, não se poderá deixar de atribuir essa qualificação aos demais princípios protegidos pela cláusula pétrea do art. 60 , $\S 4^{\circ}$, da Constituição, quais sejam, a forma federativa de Estado, a separação de Poderes e o voto direto, secreto, universal e periódico. Por outro lado, a própria Constituição explicita os chamados ‘princípios sensíveis', cuja violação pode dar ensejo à decretação de intervenção federal nos Estados-Membros (art. 34, VII). É fácil ver que a amplitude conferida às cláusulas pétreas e a idéia de unidade da Constituição (Einheit der Verfassung) acabam por colocar parte significativa da Constituição sob a proteção dessas garantias. (...) O efetivo conteúdo das 'garantias de eternidade' somente será obtido mediante esforço hermenêutico. Apenas essa atividade poderá revelar os princípios constitucionais que, ainda que não contemplados expressamente nas cláusulas pétreas, guardam estreita vinculação com os princípios por elas protegidos e estão, por isso, cobertos pela garantia de imutabilidade que delas dimana. Os princípios merecedores de proteção, tal como enunciados normalmente nas chamadas 'cláusulas pétreas', parecem despidos de conteúdo específico. Essa orientação, consagrada por esta Corte para os chamados 'princípios sensíveis’, há de se aplicar à concretização das cláusulas pétreas e, também, dos chamados 'preceitos fundamentais'. (...) É o estudo da ordem constitucional no seu contexto normativo e nas suas relações de interdependência que permite identificar as disposições essenciais para a preservação dos princípios basilares dos preceitos fundamentais em um determinado sistema. (...) Destarte, um juízo mais ou menos seguro sobre a lesão de preceito fundamental consistente nos princípios da divisão de Poderes, da forma federativa do Estado ou dos direitos e garantias individuais exige, preliminarmente, a identificação do conteúdo dessas categorias na ordem constitucional e, especialmente, das suas relações de interdependência. Nessa linha de entendimento, a lesão a preceito fundamental não se configurará apenas quando se verificar possível afronta a um princípio fundamental, tal como assente na ordem constitucional, mas também a disposições que confiram densidade normativa ou significado específico a esse princípio. Tendo em vista as interconexões e interdependências dos princípios e regras, talvez não seja recomendável proceder-se a uma distinção entre essas duas categorias, fixando-se um conceito extensivo de preceito fundamental, abrangente das normas básicas contidas no texto constitucional. (ADPF 33-MC, voto do Min. Gilmar Mendes, julgamento em 29-10-03, DJ de 6-8-04)
}

12 ARGÜIÇÃO DE DESCUMPRIMENTO DE PRECEITO FUNDAMENTAL. A QUESTÃO DA LEGITIMIDADE CONSTITUCIONAL DO CONTROLE E DA INTERVENÇÃO DO PODER JUDICIÁRIO EM TEMA DE IMPLEMENTAÇÃO DE POLÍTICAS PÚBLICAS, QUANDO CONFIGURADA HIPÓTESE DE ABUSIVIDADE GOVERNAMENTAL. DIMENSÃO POLÍTICA DA JURISDIÇÃO CONSTITUCIONAL ATRIBUÍDA AO SUPREMO TRIBUNAL FEDERAL. INOPONIBILIDADE DO ARBÍTRIO ESTATAL À EFETIVAÇÃO DOS DIREITOS SOCIAIS, ECONÔMICOS E CULTURAIS. CARÁTER RELATIVO DA LIBERDADE DE CONFORMAÇÃO DO LEGISLADOR. CONSIDERAÇÕES EM TORNO DA CLÁUSULA DA "RESERVA DO POSSÍVEL". NECESSIDADE DE PRESERVAÇÃO, EM FAVOR DOS INDIVÍDUOS, DA INTEGRIDADE E DA INTANGIBILIDADE DO NÚCLEO CONSUBSTANCIADOR DO “MÍNIMO EXISTENCIAL". VIABILIDADE INSTRUMENTAL DA ARGÜIÇÃO DE DESCUMPRIMENTO NO PROCESSO DE CONCRETIZAÇÃO DAS LIBERDADES POSITIVAS (DIREITOS CONSTITUCIONAIS DE SEGUNDA GERAÇÃO).” (STF - Pleno - MC ADPF n. 45- Rel. Min. Celso de Melo, julgamento 29/04/04, DJ de 04-05-04) 
a) Os princípios do título I da Constituição Federal, que fixam as estruturas básicas de configuração política do Estado (art. $1^{\circ}$ ao $4^{\circ}$, da CF/88);

b) Os direitos e garantias fundamentais (título II e demais dispositivos dispersos na $\mathrm{CF} / 88$ e os decorrentes da abertura proporcionada pelo $\S 3^{\circ}$, do art. $5^{\circ}$, da $\mathrm{CF} / 88$ );

c) Os princípios constitucionais sensíveis (art. 34, VII, CF/88);

d) As cláusulas pétreas (diretas - art. $60, \S 4^{\mathrm{a}}$ ou indiretas - forma de poder constituinte), e

e) As normas de proteção da Administração Pública previstas no art. 37 e seguintes da constituição.

Repise-se que os preceitos fundamentais apresentados não são numerus clausus, razão pela qual estão dispersos em todo o texto constitucional. Esta característica de rol exemplificativo das decisões do Supremo presta homenagem ao caráter dinâmico da constituição.

Neste quadro de maior clareza de identificação dos preceitos fundamentais, ainda cabe destacar que ADPF também pode ser manejada na defesa de normas constitucionais implícitas.

Isso porque as normas que podem ser extraídas da interpretação lógica do texto constitucional, embora não explicitas, também estão albergadas na proteção oferecida pela arguição de descumprimento de preceito fundamental, como se verifica na impossibilidade de modificação do procedimento especial de emenda constitucional (art. 60, §2º da CF/88), bem como a vedação de alteração dos títulos considerados cláusulas pétreas (art. 60, §4 ${ }^{\mathrm{a}}$, da $\mathrm{CF} / 88)$.

Por fim, mas não menos importante, cabe questionar se os preceitos fundamentais de que trata o $\S 1^{\circ}$, do art. 102, da Constituição Federal de 1988, apenas se referem às normas constantes do texto constitucional, ou se abrange outras normas não previstas na atual Constituição brasileira.

A resposta para esta indagação é que todas as normas infraconstitucionais, mesmos as supranacionais, não ensejam o ajuizamento da ADPF. No entanto, resta ainda os preceitos constantes de constituições anteriores.

Ora, o Supremo Tribunal Federal ainda mantém o entendimento segundo o qual o controle de constitucionalidade de uma lei ou ato normativo apenas pode ser realizado a partir da Constituição em vigor no momento de sua edição ou promulgação, daí se extrai que os preceitos fundamentais de constituições anteriores ainda servem de parâmetro, essencialmente, para o controle difuso de constitucionalidade. Já no controle concentrado, os preceitos fundamentais de constituições anteriores têm especial relevância na ADPF, uma vez 
que antes de verificar a violação dos preceitos fundamentais da Constituição atual, o Supremo examina a validade da norma em relação ao ordenamento constitucional anterior.

Eis, portanto, apresentadas as notas essenciais que devem ser tratadas acerca dos preceitos fundamentais, de modo que se possa compreender porque as limitações impostas pela jurisprudência da Suprema Corte à ADPF fazem com que não consiga realizar com exação o seu objetivo de salvaguarda dos preceitos fundamentais.

\section{3) “DESCUMPRIMENTO” DE PRECEITO FUNDAMENTAL POR ATO DO PODER PÚBLICO}

A inconstitucionalidade objeto de ADIN é a ausência de compatibilidade da Constituição com as normas infraconstitucionais que regulam diretamente assuntos constitucionais, razão pela qual, afirma-se que é pressuposto de controle de constitucionalidade que a norma viole a Constituição de forma primária ou imediata.

Em princípio, na comparação entre o descumprimento do preceito fundamental e o controle de constitucionalidade da ADIN, cabe apontar duas peculiaridades da ADPF, quais sejam: 1) o parâmetro de controle é restrito aos preceitos fundamentais, conforme já foi apresentado; 2) presta-se à apreciação de atos do poder público.

Assim, o descumprimento tutelado pela ADPF apenas será verificado quando uma ação ou omissão estatal violar preceito fundamental. Ora, em contraposição à ADIN cujo parâmetro de controle é toda a Constituição, na ADPF este espectro estará cingido aos preceitos fundamentais.

Além do parâmetro, outro ponto de especial relevância é o objeto de controle, isso porque a ADPF foi prevista na Constituição Federal de 1988 como uma ação de defesa das normas essências à manutenção da sociedade. No entanto, o legislador infraconstitucional restringiu o objeto deste importante instituto, limitando-o ao controle dos atos do Poder Público e perdendo a oportunidade de abarcar os atos privados inerentes a eficácia horizontal das normas constitucionais.

A Lei $\mathrm{n}^{\circ}$. 9.882/99 apenas menciona no caput de seu art. $1^{\circ}$, a finalidade da ADPF de evitar ou reparar lesão a preceito fundamental decorrente de ato do Poder Público, sem, no entanto, delimitar quais seriam esses atos.

A atividade de delimitar o campo de aplicação da ADPF coube à doutrina e de forma, altamente reducionista, à jurisprudência da Suprema Corte brasileira. 
Em que pese tratarmos mais detidamente, no próximo tópico, acerca das limitações interpretativas do STF à importantíssima ADPF, cabe esclarecer em que consiste ato do Poder Público.

Poder Público é qualquer órgão ou entidade dos Poderes Legislativo e Executivo dos entes políticos, bem como o Poder Judiciário da União, dos Estados-Membros e do DistritoFederal. Por sua vez, o ato do Poder Público suscitado na lei regulamentadora da ADPF refere-se aos quatro entes federados (União, Estados, Distrito Federal e Municípios) e pode ser traduzido como: 1) lei ou ato normativo; 2) ato concreto do poder público; 3) atos secundários de disciplina da norma constitucional; 4) direito pré-constitucional, e 5) as omissões controláveis.

Ocorre que o ato do Poder Público previsto na Lei no . 9.882/99 tem seu âmbito frequentemente reduzido pelo STF e o direito pátrio tem perdido a oportunidade de utilizar o instituto da ADPF na potencialidade que poderia ter na defesa dos preceitos fundamentais.

Uma dessas restrições da jurisprudência do Supremo será objeto de análise e crítica no tópico seguintes, qual seja, o controle judicial dos atos políticos, tendo em conta a relevância do tema para o direito pátrio.

\section{4) CONTROLE JUDICIAL DE ATOS POLÍTICOS}

A doutrina majoritária ${ }^{13}$ há muito tem rechaçado o controle judicial dos atos políticos e interna corporis sob o argumento central de que deveria ser preservada a separação dos poderes. Esta concepção decorre de uma adesão à doutrina francesa sem a devida observância da realidade jurisdicional brasileira, pois, diferentemente da França, onde desde a Revolução Francesa a jurisdição é dual, ou seja, existe a jurisdição comum e a jurisdição administrativa, esta última específica para as contendas envolvendo o Estado, no Brasil adotou-se a jurisdição una, em que, independente das partes do processo, o julgamento caberá ao Poder Judiciário ${ }^{14}$.

\footnotetext{
13 Nesse sentido: Oswaldo Aranha Bandeira de Mello (Princípios Gerais de Direito Administrativo - Vol. I. São Paulo: Malheiros, 2007); Hely Lopes Meirelles (Direito Administrativo Brasileiro. 39a Ed. São Paulo: Malheiros. 2013) e Marçal Justen Filho (Curso de Direito Administrativo. 12ª ed. São Paulo: Saraiva, 2016).

${ }^{14}$ Nesse sentido pondera o Wilson Alves Souza ao tratar sobre jurisdição e o princípio democrático: (...) "no plano interno, não há outra solução: o Estado julga o próprio Estado. No entanto o Estado só pode exercer a função jurisdicional por meio de órgãos instituídos a partir da constituição, composto de outros agentes providos de independência e imparcialidade, ficando aquele no dever de se submeter ao seu próprio julgamento. Do contrário, não haverá acesso à jurisdição nem democracia. (Jurisdição, garantias, direitos e deveres fundamentais. In SOUZA, Wilson Alves (Coord.) Estudos de Direito Processual Civil. Salvador: Dois de Julho, 2014. P. 28). O posicionamento do doutrinador pode ser observado também na
} 
Não bastasse o equívoco genealógico do posicionamento majoritário, a Constituição brasileira de 1988 consagrou o princípio da inafastabilidade do controle jurisdicional ${ }^{15}$, razão pela qual qualquer lesão ou ameaça de lesão a direito subjetivo pode ser levada à apreciação do Poder Judiciário. Assim, todos os atos do Poder Público, nestes já considerados os atos políticos e os atos interna corporis, estariam sujeitos ao controle jurisdicional.

Partindo-se dessa premissa, necessária a análise acerca da possibilidade do controle jurisdicional dos atos políticos propriamente ditos e dos atos políticos interna corporis.

Neste ponto, cabe aclarar que não se objetiva traçar as diferenças entre atos políticos e o que entendemos ser uma de suas espécies, os atos intena corporis ${ }^{16}$. Estes últimos entendidos como atos de organização e economia do Poder Legislativo e Judiciário e de órgãos colegiados em geral, dentre os quais: a eleição dos membros do órgão diretivo, verificação de poderes e incompatibilidade de seus membros (cassação de mandatos, concessão de licenças etc.) e os de utilização de suas prerrogativas institucionais (modo de funcionamento do órgão legislativo, elaboração de regimento, constituição de comissões, organização de serviços auxiliares etc.) e a valoração das votações ${ }^{17}$. A doutrina apresenta como requisitos distintivo dos atos interna corporis em relação aos atos políticos e também como razões para a sua não apreciação pelo Poder Judiciário, os seguintes fundamentos: 1) o fato de serem disciplinados pelo regimento interno da casa legislativa ou do órgão colegiado; 2) a restrição dos efeitos do ato aos membros do órgão decisório ${ }^{18}$, e 3) a possibilidade de serem praticados por órgãos administrativos.

Apesar dos referidos fundamentos, os atos políticos e os atos interna corporis do Poder Público apresentam uma relevante intercepção, que se insere, deveras, no objeto do

obra A Jurisdição. In SOUZA, Wilson Alves (Coord.) O Direito Processual em Transformação. Salvador: Dois de Julho, 2014.

${ }^{15}$ Art. 5ํ XXXV - a lei não excluirá da apreciação do Poder Judiciário lesão ou ameaça a direito;

${ }^{16}$ A título de esclarecimento, este trabalho considera que "atos políticos” e "atos interna corporis" são distintos, mas que estes últimos contemplam atribuições constitucionais a órgãos e entidades específicas, o que os torna, nesse aspecto, uma espécie de ato político.

${ }^{17}$ CRETELLA JÚNIOR, José. Dos Atos Administrativos Especiais. 2. ed. Rio de Janeiro: Editora Forense, 1998. p. 162

\footnotetext{
${ }^{18}$ Nesse sentido, pontifica Wilson Alves de Souza: “Atos interna corporis, como o nome sugere, são aqueles praticados no âmbito de determinado órgão ou entidade, relacionado com o próprio órgão ou entidade e seus componentes, desde que não diga respeito a direitos subjetivos desses componentes. Assim, se o ato envolve terceiros, não pode ser qualificado como interna corporis.” (Acesso à Justiça. Salvador: Dois de Julho, 2011.p. 241)
} 
presente estudo, uma vez que os atos interna corporis despidos da função administrativa são verdadeiros atos políticos, já quanto aos demais requisitos distintivos, entende-se em consonância com a doutrina de Wilson Alves de Souza que: 1) a irregularidade na aplicação do regimento interno também enseja o controle jurisdicional, e 2) existe a possibilidade de ameaça de lesão ou lesão a direito subjetivo de terceiros ou dos próprios membros do órgão colegiado, o que seria o bastante a ensejar o controle do Poder Judiciário ${ }^{19}$.

Delineado que o objeto desse estudo são os atos políticos, mesmo quando praticados no seio de órgãos colegiados, estes são compreendidos como os atos de competência da alta cúpula dos poderes constituídos, que decorrem de diretrizes ideológicas adotadas pelo Estado em um dado momento. Tratam-se de atribuições expressamente estabelecidas na Constituição para os agentes estatais e que não apresentam aspecto de ato administrativo ${ }^{20}$. São exemplos de atos políticos: a sanção de lei, o veto jurídico, a iniciativa de lei, a decretação de estado de defesa e de estado de sítio, os atos de deliberação do Congresso Nacional, dentre outros.

Nesse sentido, Maria Sylvia Zanella Di Pietro pontifica que o ato político implica uma atividade de ordem superior referida à direção suprema e geral do Estado em seu conjunto e em sua unidade, dirigida a determinar os fins da ação do Estado, a assinalar as diretrizes para as outras funções, buscando a unidade da soberania estatal ${ }^{21}$.

Ora, os atos políticos estão relacionados à conveniência e à oportunidade política dos Poderes Executivo, Legislativo ou Judiciário, razão pela qual são atos praticados pelo Poder Público.

Por sua vez, o objeto da ADPF é evitar ou reparar lesão a preceito fundamental, resultante de ato do Poder Público, portanto, sendo os atos políticos espécies desses, a ação constitucional deveria prestar-se a seu controle. No entanto, o Supremo Tribunal Federal firmou entendimento por afastar esses atos de sua sindicabilidade, por meio de ADPF.

\footnotetext{
${ }^{19}$ Wilson Alves de Souza trata da matéria com precisão: “Em resumo, não se pode afirmar a priori que os atos interna corporis são imunes a controle jurisdicional, vez que tal generalização pode resultar em negação do acesso à justiça. $\mathrm{O}$ fundamental em relação a tais atos é saber se se invoca violação de algum direito subjetivo, não tendo a mínima importância o tipo de norma em questão nem o fato de o impugnante ser componente do órgão que praticou o ato que se quer atacar ou mesmo se referir a suas funções como integrante desse órgão.” (Acesso à Justiça. Salvador: Dois de Julho, 2011.p. 246).

${ }^{20}$ MEIRELLES, Hely Lopes. Direito Administrativo Brasileiro, 39a Ed. São Paulo: Malheiros. 2013. p. 680. e DI PIETRO, Maria Sylvia Zanella. Direito administrativo. .28 Ed. São Paulo: Grupo Gen, 2015. p. 178.

${ }^{21}$ Op Cit. p. 178.
} 
Dirley da Cunha Jr. pondera que a Suprema Corte brasileira perdeu importante oportunidade de garantir a normatividade plena à Constituição Federal de 1988 e afastá-la da sina de se tornar uma Constituição nominal ou de "fachada”, conforme a classificação de Carl Loewenstein $^{22}$.

A jurisprudência do Supremo restou consolidada logo na ADPF $n^{\circ}$. 01-RJ movida pelo Partido Comunista do Brasil - PcdoB em face do Prefeito do Município do Rio de Janeiro, uma vez que este não motivara o ato de veto de uma lei que havia elevado o valor do IPTU para o exercício de 2000. Ocorre que, embora a Constituição estabeleça que o veto político do chefe do Poder Executivo deva ser motivado (Art. 66, §1 ${ }^{\circ}$, da CF/88), o STF decidiu por não conhecer a ADPF, uma vez que se tratava de ato político ${ }^{23}$.

Este episódio constitui ofensa direta ao princípio da inafastabilidade do controle pelo Poder Judiciário, direito fundamental constante do art. 5º, inciso XXXV, da CF/88. Acreditase que este entendimento deve ser superado à semelhança do já admitido controle judicial dos atos administrativos discricionários, ou seja, aqueles em que a Administração Pública atua por razões de conveniência e oportunidade.

A aplicação desse entendimento aos atos administrativos deve ser estendida aos atos políticos até porque se tratam de espécies de atos do Poder Público. Por esta razão, ambos têm

\footnotetext{
${ }^{22}$ Op Cit. p. 325.

${ }^{23}$ Arguição de descumprimento de preceito fundamental. Lei $\mathbf{n}^{\circ}$ 9882, de 3.12.1999, que dispõe sobre o processo e julgamento da referida medida constitucional. (...) 6. 0 objeto da arguição de descumprimento de preceito fundamental há de ser "ato do Poder Público" federal, estadual, distrital ou municipal, normativo ou não, sendo, também, cabível a medida judicial "quando for relevante o fundamento da controvérsia sobre lei ou ato normativo federal, estadual ou municipal, incluídos os anteriores à Constituição". 7. Na espécie, a inicial aponta como descumprido, por ato do Poder Executivo municipal do Rio de Janeiro, o preceito fundamental da "separação de poderes", previsto no art. $2^{\circ}$ da Lei Magna da República de 1988. O ato do indicado Poder Executivo municipal é veto aposto a dispositivo constante de projeto de lei aprovado pela Câmara Municipal da Cidade do Rio de Janeiro, relativo ao IPTU. 8. No processo legislativo, o ato de vetar, por motivo de inconstitucionalidade ou de contrariedade ao interesse público, e a deliberação legislativa de manter ou recusar o veto, qualquer seja o motivo desse juízo, compõem procedimentos que se hão de reservar à esfera de independência dos Poderes Políticos em apreço. 9. Não é, assim, enquadrável, em princípio, o veto, devidamente fundamentado, pendente de deliberação política do Poder Legislativo - que pode, sempre, mantê-lo ou recusá-lo, - no conceito de "ato do Poder Público", para os fins do art. $1^{\circ}$, da Lei $\mathbf{n}^{\mathbf{0}}$ 9882/1999. Impossibilidade de intervenção antecipada do Judiciário, - eis que o projeto de lei, na parte vetada, não é lei, nem ato normativo, - poder que a ordem jurídica, na espécie, não confere ao Supremo Tribunal Federal, em via de controle concentrado. 10. Arguição de descumprimento de preceito fundamental não conhecida, porque não admissível, no caso concreto, em face da natureza do ato do Poder Público impugnado. (ADPF 1-QO/RJ, Relator Ministro Néri da Silveira, Tribunal Pleno, DJ 07.11.2003, destaquei)
} 
como requisitos necessários: forma, competência, objeto, motivo e finalidade. O Poder Judiciário, quanto aos atos administrativos discricionários, tem admitido a análise da legalidade desses requisitos, o que se defende, mutatis mutandis, deva também ser aplicado aos atos políticos.

Assim, episódios como o da ADPF nº 01-RJ deveriam ser admitidos e a análise meritória circunscrever-se à análise dos requisitos forma, competência, objeto, motivo e finalidade. Em especial, na hipótese do referido julgamento, a ação constitucional deveria ter sido conhecida e julgada procedente, em virtude da ausência do atendimento ao requisito constitucional motivo.

Situações semelhantes têm chegado à corte Suprema e têm recebido o mesmo tratamento da ADPF $\mathrm{n}^{\circ}$. 01-RJ. Neste sentido, pode-se mencionar a ADPF $\mathrm{n}^{\circ}$. 372-DF, de Relatoria da Ministra Rosa Weber, ajuizada pela Associação dos Membros dos Tribunais de Contas do Brasil - Atricon contra o veto total da Presidência da República ao Projeto de Lei do Senado 274/2015, que versava sobre a aposentadoria compulsória dos servidores efetivos e vitalícios aos 75 (setenta e cinco) anos de idade ${ }^{24}$. Um dos motivos apresentados pela ministra para não conhecer a ADPF foi a inadequação do objeto, uma vez que não se subsome ao requisito legal do art. $1^{\text {a }}$, caput, da Lei $n^{\circ}$. 9.882/99, qual seja, “ato do Poder Público”, tratando-se de um ato político, que, conforme os fundamentos da decisão monocrática, ainda poderia ser objeto de rejeição do veto pelo Congresso Nacional, o que aliás acabou por se ultimar, dando origem à Lei Complementar nº 152/2015.

Episódio semelhante aconteceu na $\operatorname{ADPF} n^{\circ}$. 73, quando o Ministro Eros Grau não conheceu da ação, uma vez que impugnava veto parcial do Presidente da República oposto a Lei ${ }^{\circ}$. 10.934/2004, Lei de Diretrizes Orçamentárias de $2005^{25}$.

\footnotetext{
${ }^{24}$ 1. Trata-se de arguição de descumprimento de preceito fundamental proposta pela ASSOCIAÇÃO DOS MEMBROS DOS TRIBUNAIS DE CONTAS DO BRASIL - ATRICON em face do veto presidencial oposto à íntegra do Projeto de Lei Complementar do Senado ${ }^{\circ}$ 274/2015, que dispõe sobre a aposentadoria compulsória aos setenta e cinco anos de idade, com proventos proporcionais ao tempo de contribuição, no âmbito da União, dos Estados, do Distrito Federal e dos Municípios, consoante veiculado na Mensagem no 441/2015 da Presidência da República. (...) 11. À luz do exposto, o veto presidencial fundamentado, pendente de deliberação política do Congresso Nacional, de modo algum se amolda à figura de "ato do Poder Público” para os fins do art. $1^{\circ}$, caput, da Lei n ${ }^{\circ}$ 9.882/1999. 12. Forte nos arts. $4^{\circ}$, caput, da Lei $n^{\circ} 9.882 / 1999$ e 21 , § $1^{\circ}$, do RISTF, nego seguimento à presente arguição de descumprimento de preceito fundamental, prejudicado o exame do pedido de liminar. (STF. ADPF 372-DF. Processo n. 0007934-95.2015.1.00.0000. Rel. Min. Rosa Weber. Julgado em 03/11/2015)
}

\footnotetext{
25 1. O Partido da Social Democracia Brasileira - PSDB propõe argüição de descumprimento de preceito fundamental, com pedido de liminar, indicando como ato lesivo o veto parcial do Presidente da República ao Projeto de Lei n. 3, de 2004 - CN,
} 
A questão da apreciação de atos políticos pelo Poder Judiciário reside, sobretudo, na proteção aos preceitos fundamentais. Esta possibilidade viria a sedimentar o entendimento de que a finalidade de evitar ou reparar a lesão a preceitos fundamentais está acima da grande maioria dos atos que possam ser praticados pelo Poder Público.

O controle judicial dos atos políticos pode ser dividido em três correntes com entendimentos diversos, quais sejam: primeiro, o atual entendimento do STF, segundo o qual os atos de natureza política não podem ser sindicados; segundo, a posição da doutrina que admite que alguns atos políticos estariam sujeitos ao controle do Poder Judiciário e outros estariam apenas relacionados à conveniência e oportunidade política do Poder responsável ${ }^{26}$ e, em terceiro lugar, o posicionamento que aderimos, segundo o qual, todo e qualquer ato político pode ser sindicado, com o objetivo de evitar ou reparar lesão a preceito fundamental.

Ora, a constituição é a lei fundamental do Estado e os preceitos fundamentais lhe emprestam o espírito, ou seja, são as normas indispensáveis à conservação jurídica e política da ordem constitucional, razão pela qual esses preceitos devem prevalecer em face de qualquer ato do Estado, quando atentem contra os requisitos de formação do ato ou possam ser adotadas medidas menos gravosas ou mais benéficas para a sociedade.

\section{5) CONCLUSÃO}

que resultou na Lei n. 10.934, de 11 de agosto de 2.004. A lei mencionada dispõe sobre diretrizes para a elaboração da lei orçamentária de 2.005. 2. O argüente sustenta que seria patente o cabimento desta ADPF. Isso porque o ato de que se trata, veto a lei de diretrizes orçamentárias, não seria impugnável pela via da ação direta. Diz que Supremo Tribunal Federal entende que as leis de diretrizes orçamentárias consubstanciam atos de efeitos concretos. 3. Alega que o veto ao $\S 3^{\circ}$ da Lei n. 10.934 violaria "os preceitos fundamentais da dignidade da pessoa humana, do direito a vida, do direito a saúde e da garantia de recursos financeiros mínimos a serem aplicados nas ações e serviços públicos da saúde, constantes, respectivamente, dos artigos $1^{\circ}$, inciso III, $5^{\circ}$, caput, $6^{\circ}$, caput, 196, todos da Constituição Federal, além do inserto no artigo 77 do Ato das Disposições Transitórias, com redação dada pela Emenda Constitucional n. 29” (...) 11. O argüente afirma que o veto presidencial ao $\S 3^{\circ}$ do artigo 59 da Lei 10.934 consubstanciaria lesão a preceito fundamental. Isso porque “o piso de aplicação em saúde em 2005 deveria estar sob a égide da Lei Complementar prevista na EC $n^{\circ}$ 29, porém a sua não aprovação até o momento implica na continuidade das regras estabelecidas para os exercícios de 2001 a 2004, estatuídas no inciso I, alínea 'b’, do artigo 771. (...)13. A presente argüição de descumprimento de preceito fundamental carece de condições que viabilizem o seu prosseguimento. Nego seguimento à argüição nos termos do art. 21, § $1^{\circ}$, do RISTF. (ADPF 73-DF. STF. Rel. Min. Eros Graus DJ 11/05/2007 PP-00122 RDDP n. 52, 2007, p. 156-158).

${ }^{26}$ Nesse sentido, Dirley da Cunha Jr. e Luís Roberto Barroso. 
As concepções de Estado de Direito, preceitos fundamentais, atos políticos e da própria arguição de descumprimento de preceito fundamental estão diretamente relacionados ao objeto e à conclusão do presente estudo.

Isso porque, desvelou-se que o Estado de Direito é a garantia da sociedade em face do Poder Público, que tem a obrigação de atuar em total observância às normas jurídicas e, sobretudo, às normas constitucionais.

Por sua vez, dentre as normas constitucionais (princípios e regras) existem aquelas que são especialmente valoradas, pois dizem respeito à própria essência, ao espírito que anima a lei fundamental, chamadas de preceitos fundamentais. Tratam-se de normas de caráter dinâmico, que são alçadas a este patamar a depender do momento por que passa à sociedade e a composição ideológica do tribunal ao qual, em último grau, compete a interpretação da constituição. Por essa razão, laborou bem o constituinte e o legislador infraconstitucional ao não estabelecer um rol taxativo desses preceitos.

Ocorre que, por vezes, o ato do Poder Público está em desconformidade com os preceitos fundamentais, razão pela qual o constituinte fez constar na Constituição Federal de 1988 um instrumento com objetivo de ser o verdadeiro guardião da essência constitucional, qual seja, a arguição de descumprimento de preceito fundamental.

A previsão constitucional e a legal (Lei ${ }^{\circ}$. 9.882/99) não foram suficientes para garantir que todos os atos do Poder Público fossem controláveis por meio de ADPF, uma vez que a Suprema Corte brasileira, perdendo importante oportunidade de garantir a normatividade plena à Constituição Federal de 1988, firmou jurisprudência no sentido de não estender esta proteção aos atos políticos.

Este entendimento está fundado na independência e harmonia entre os Poderes constituídos prevista no art. $2^{\circ}$, da CF/88, mas deixa desguarnecido o Estado de Direito e desconsidera a importância do sistema de freios e contrapesos.

Eis que, na contramão do entendimento do STF, este estudo defende que os atos políticos, ou seja, aqueles de competência da alta cúpula dos Poderes Constituídos, que decorrem de diretrizes ideológicas adotadas pelo Estado em um dado momento, devam ser objeto de controle pelo Poder Judiciário.

A justificativa reside na própria essencialidade e indisponibilidade dos preceitos fundamentais para a manutenção do Estado Constitucional de Direito, razão porque, em regra, não podem ser preteridos. 
A defesa do controle judicial dos atos políticos muito se assemelha àquela que foi $\mathrm{e}$ continua sendo travada para possibilitar a sindicabilidade judicial dos atos administrativos discricionários. Ademais, por ambos serem espécies de atos do Poder Público, acredita-se ser prudente adotar forma de controle semelhante, na qual a verificação pelo Poder Judiciário estará circunscrita à legalidade dos requisitos da prática do ato, quais sejam: forma, competência, objeto, motivo e finalidade.

As Arguições de Descumprimento de Preceito Fundamental 01-RJ, 73-DF e 372-DF foram exemplos da adoção reiterada do entendimento do Supremo Tribunal Federal em não promover o controle de atos políticos desde 1999, ano do advento da Lei $\mathrm{n}^{\circ}$. 9.882, que regulamenta o processo e julgamento da ADPF.

Acredita-se que esses posicionamentos podem ser paulatinamente suplantados pela análise da legalidade dos requisitos do ato político praticado.

Deveras já se verificam alguns avanços na jurisprudência do STF, embora nenhuma diretamente mencionando o controle de atos políticos. Isso porque na ADPF $\mathrm{n}^{\circ}$. 378-DF, a Corte se manifestou sobre o rito a ser adotado no processo de impeachment, que, embora esteja previsto na Lei $n^{\circ}$. 1.079/50, remete a um procedimento interna corporis do Congresso Nacional; já em julgado em que se desvela mais o caráter político, a Suprema Corte analisou a linha de substituição do Presidente da República, decidindo que o então Presidente do Senado Federal, réu em ação penal perante a própria corte, não poderia substituir o Presidente da República, embora pudesse se manter no cargo $^{27}$.

Observa-se que o Supremo é uma corte eminentemente política e se nega a admitir a importância do controle judicial dos atos políticos, entendimento que espera seja alterado em breve, possibilitando a efetiva defesa dos preceitos fundamentais a que se presta a arguição de descumprimento de preceito fundamental, bem como que a Constituição Federal de 1988 seja alçada a uma normatividade plena impulsionada pelo controle jurisdicional.

\footnotetext{
${ }^{27}$ Eis o dispositivo da decisão monocrática do Min. Marco Aurélio Mello no bojo da ADPF 402/DF: “3. Defiro a liminar pleiteada. Faço-o para afastar não do exercício do mandato de Senador, outorgado pelo povo alagoano, mas do cargo de Presidente do Senado o senador Renan Calheiros. Com a urgência que o caso requer, deem cumprimento, por mandado, sob as penas da Lei, a esta decisão.”
} 
7) REFERÊNCIAS

ALEXY, Robert. Teoria dos Direitos Fundamentais. $2^{\mathrm{a}}$ Ed. Trad. Virgílio Afonso da Silva. Malheiros: Saraiva, 2008.

ALVIM, Eduardo Arruda. Processo Constitucional. São Paulo: Revista dos Tribunais, 2014.

BARROSO, Roberto Luís. O Controle de Constitucionalidade no Direito Brasileiro. $7^{\mathrm{a}}$ ed. São Paulo: Saraiva, 2016.

BRASIL. Constituição (1988). Constituição da República Federativa do Brasil: promulgada em 5 de outubro de $1988 . \quad$ Disponível em <http://www.planalto.gov.br/ccivil_03/constituicao/constituicao.htm>. Acesso em 06 mar. 2017

. Lei n. 9.882, de 03.12.1999. Dispõe sobre o processo e julgamento da argüição de descumprimento de preceito fundamental, nos termos do $\S 1^{0}$ do art. 102 da Constituição Federal. $\quad$ Planalto. Disponível em < http://www.planalto.gov.br/ccivil_03/constituicao/constituicaocompilado.htm>. Acesso em 07 mar. 2017.

Supremo Tribunal Federal. ADPF 1/RJ. Rel. Min. Néri da Silveira. Tribunal Pleno. Julgado em 03.02.2000. Publicado em 07.11.2003.

Supremo Tribunal Federal. ADPF 17/AP. Rel. Min. Celso de Mello. Tribunal Pleno. Julgado em 20.09.2001. Publicado em 28.09.2001.

. Supremo Tribunal Federal. ADPF 33 MC/PA, voto do Relator. Rel. Min. Gilmar Mendes. Tribunal Pleno. Julgado em 29.10.2003. Publicado em 06.08.2004.

. Supremo Tribunal Federal. ADPF 45 MC/DF. Rel. Min. Celso de Melo. Tribunal Pleno. Julgado em 29.04.2004. Publicado em 04.05.2004. 
. Supremo Tribunal Federal. ADPF 372/DF. Rel. Minª. Rosa Weber. Tribunal Pleno. Julgado em 03.11.2015. Publicado em 06.11.2015.

. Supremo Tribunal Federal. ADPF 73/DF. Rel. Minª Eros Graus. Tribunal Pleno. Julgado em 07.05.2007. Publicado em 11.05.2007.

. Supremo Tribunal Federal. ADPF 73/DF. Rel. Minª Eros Graus. Tribunal Pleno. Julgado em 07.05.2007. Publicado em 11.05.2007.

. Supremo Tribunal Federal. Agravo Regimental 1.140-7/TO. Rel. Minª. Sydney Sanches. Tribunal Pleno. Publicado em 31.05.1996.

CAPPELLETTI, Mauro. O Controle Judicial de Constitucionalidade de Leis no Direito Comparado. São Paulo: Sérgio Fabris, 2014.

CRETELlA JÚNIOR, José. Dos Atos Administrativos Especiais. 2. ed. Rio de Janeiro: Editora Forense, 1998.

CUNHA JR, Dirley da. Controle de Constitucionalidade: teoria e prática. $8^{\mathrm{a}}$ ed. Salvador: JusPodivm, 2016.

Arguição de descumprimento de preceito fundamental. In: DIDIER JUNIOR, Fredie (Org.). Ações constitucionais. 4. ed. Salvador: JusPODIVM, 2009. p. 488-503.

DI PIETRO, Maria Sylvia Zanella. Direito administrativo. .28ª Ed. São Paulo: Grupo Gen, 2015.

DICIONÁRIO AURÉLIO. Acessado em <https://contas.tcu.gov.br/dicionario/home.asp> no dia 28/03/2017.

JUSTEN FILHO, Marçal. Curso de Direito Administrativo. 12ª ed. São Paulo: Saraiva, 2016. 
MEIRELLES, Hely Lopes. Direito Administrativo Brasileiro. 39a Ed. São Paulo: Malheiros. 2013.

MELLO, Oswaldo Aranha Bandeira de. Princípios Gerais de Direito Administrativo - Vol. I. São Paulo: Malheiros, 2007.

MENDES, Gilmar Ferreira. Arguição de Descumprimento de Preceito Fundamental. $2^{\mathrm{a}}$ ed. São Paulo: Saraiva, 2011.

NERY JR., Nelson; NERY, Rosa Maria. Código de processo civil comentado e legislação processual civil extravagante em vigor. 2002.

RAMOS, Elival da Silva. Arguição de Descumprimento de Preceito Fundamental: Delineamento do Instituto. In: TAVARES, André Ramos; ROTHENBURG, Walter Claudius (Orgs.). Arguição de descumprimento de preceito fundamental: análises à luz da L. 9882/99. São Paulo: Atlas, 2002. p. 109-127.

. Controle de constitucionalidade no Brasil: perspectivas de evolução. São Paulo: Saraiva, 2010.

SOUZA, Wilson Alves. Acesso à Justiça. Salvador: Dois de Julho, 2011.

Jurisdição, garantias, direitos e deveres fundamentais. In SOUZA, Wilson Alves (Coord.) Estudos de Direito Processual Civil. Salvador: Dois de Julho, 2014.

A jurisdição. In SOUZA, Wilson Alves (Coord.) O Direito Processual em Transformação. Salvador: Dois de Julho, 2014.

TAVARES, André Ramos. Tratado de Arguição de Preceito Fundamental. São Paulo: Atlas, 2001.

VELOSO, Zeno. Controle jurisdicional de constitucionalidade. Belo Horizonte: DelRey, 2003. 